\title{
META KONSEP KEKUASAAN DAN DEMOKRASI DALAM KAJIAN TEORI POLITIK
}

\author{
ZUSIANA ELLY TRIANTINI
}

UIN SUNAN KALIJAGA YOGYAKARTA

zusiana.triantini@uin-suka.ac.id

\begin{abstract}
Abstrak
Tulisan ini akan mengupas tentang bagaimana konsep kekuasaan dikaji oleh para pemikir seperti; Foucault, Mills, Duhl, namun juga tidak kalah menarik tulisan ini ingin menyajikan sedikit perbandingan dengan pemikiran politik Islam Ibnu Kholdun dan AL Mawardi yang juga mendeskripsikan konsep politik dan power dengan rujukan term teologis. Menjadi penting memahami konsep kekuasaan dari dua belahan peradaban dunia tersebut, apalagi dalam konteks melihat politik di Indonesia. Mengapa demikian? Karena Indonesia adalah negara dengan mayoritas penduduk Muslim, meskipun bukan negara Islam namun pemikiran Islam banyak di konsumsi oleh masyarakat maupun politisi di Indonesia. Sehingga menghadirkan dua wajah peradaban yang melahirkan pemikiran tentang kekuasaan dan demokrasi menjadi penting untuk diketengahkan.
\end{abstract}

Kata Kunci: Kekuasaan, Otoritas, Legitimasi, Demokrasi

\section{A. Pendahuluan}

Entitas negara sebagai sesuatu yang mutlak adanya selama ini diterima sebagai konstruksi yang tidak terbantahkan karena keberadaan negara tidak disadari secara penuh oleh manusia. Negara bisa disadari keberadaannya ketika menyentuh level individual dan ketika berbenturan dengan kekuasaan. Hadirnya kekuasaan negara dalam berbagai bentuk namun bukan sebagai representasi kepentingan masyarakat maka keberadaannya akan berbenturan dengan kekuasaan masyarakat yang dimainkan oleh sekelompok orang yang menyebut dirinya sebagai representasi masyarakat. Di sinilah kekuasaan kemudian bermain dan negosiasi atas kekuasaan berjalan sehingga akan ditemukan siapa sesungguhnya yang memiliki power lebih besar antara negara dan masyarakat.

Kekuasaan adalah gagasan yang seringkali membingungkan. Yang seolah hanya bisa digunakan untuk berbicara tentang politik dalam wacana yang biasa. Namun jika konsep kekuasaan digunakan untuk menganalisis secara sitematis 
politik maka kekuasaan akan berubah menjadi semacam gumpalan konsep besar yang makna dan sifatnya semakin tidak jelas dan samar. ${ }^{1}$

Oleh karena itu, menjadi penting untuk menjernihkan konsep kekuasaan itu sendiri untuk mencapai tingkat analisis yang dalam dalam menganalisa kondisi politik yang selalu berubah dari waktu ke waktu. Kekuasaan jika hanya dilihat dari aspek yang kuat akan menguasai dan yang lemah akan dikuasai, maka kesimpulan dalam setiap analisa hanya akan menghasilkan analisa yang dangkal dan tidak mendalam. Kekuasaan selalu diperdebatkan oleh banyak pemikir dengan berbagai argumen yang dikemukakan. Perdebatan tentang kekuasaan dari model scintific yang sangat matematis dan seolah terhitung pasti hingga kekuasaan yang dideskripsikan secara abtraks akan dikupas dalam tulisan ini.

\section{B. Power}

Karya-karya monumental dan pemikiran-pemikiran politik beberapa sosiolog banyak berbicara power dengan merujuk pada konsep besar Marx dan Weber. Politik dalam kacamata Marx (1818 -1883) yang disebut memiliki konsep politik tradisional menyebut politik sebagai aparatur negara yang merujuk pada kekuatan kelas yang terorganisir untuk menekan atau menindas yang lain yang pada akhirnya memunculkan teori kelas. ${ }^{2}$

Sebagian besar ilmuan juga mendeskripsikan konsep kekuasaan merujuk pada konsep Weber atau mengutip dari pendapat ilmuan lain tanpa berusaha mengurangi ambiguitas dan abstraksi yang terkait sehingga konstruksi kekuasaan pada umumnya menjadi subyek yang diabaikan secara analitis. ${ }^{3}$

Max Weber (1864 -1920) mengartikan kekuasaan itu adalah sebuah kemampuan untuk membuat orang lain mau menerima dan melakukan apa yang menjadi kemauan kita walau mungkin hal tersebut tidak disetujui, bahkan ditentang. ${ }^{4}$

\footnotetext{
${ }^{1}$ Norman Uphoff, Distinguishing Power, Authority \& Legitimacy: Taking Max Weber at his Word by Using Resources-ExchangeA nalysis (Journal Polity, Vol. 22, No. 2 1989), hlm. 296

${ }^{2}$ Andrew Heywood, Political Theory : an Introduction (New York: Palgrave Macmilan, 2004), hlm. 60.

${ }^{3}$ Norman Uphoff, Distinguishing Power, hlm. 297

${ }^{4}$ Miriam Budiarjo, Dasar-dasar Ilmu Politik (Jakarta : Gramedia Pustaka Utama, 2008)
} 
C Wright Mills (1916 -1962) mendiskripsikan bagaimana power bekerja tanpa disadari oleh orang-orang di sekitarnya. Mills mengambarkan bagaimana kekuatan manusia yang biasa dibatasi oleh lingkungan mereka (tempat tinggal, keluarga dan tempat bekerja, dll) yang memiliki kekuatan besar dan mendorong mereka untuk melakukan sesuatu tanpa dimengerti dan dipahami. Mereka melakukan 'Perubahan besar' yang berada di luar kendali mereka, namun tidak sedikitpun mempengaruhi perilaku dan pandangan mereka.. Kekuasaan digambarkan dengan drama elite yang duduk di pengambil keputusan, seperti orang-orang yang duduk di level komando dan organisasi masyarakat modern. ${ }^{5}$

Pandangan Mills ini didukung oleh Talcot Parsons (1902 - 1979) dengan menggambarkan bahwa kekuasaan dimiliki oleh seseorang atau kelompok tertentu sampai pada derajat atau tingkat yang tidak dimiliki oleh orang atau kelompok kedua yang tidak memiliki kekuasaan. ${ }^{6}$ Hakikat kekuasaan dalam pandangan Parsons adalah kemungkinan untuk memaksakan kehendak kepada seseorang terhadap perilaku orang lain. Dalam konteks ini semua pihak akan diuntungkan karena dengan pelaksaan power ini, yang terkena power pun atau pihak kedua juga akan diuntungkan selama kekuasan tersebut mendapatkan legitimasi. Konsep ini lebih dikenal dengan zero -sum power.

Perdebatan konsep kekuasaan terus berjalan seiring bergulirnya waktu dan pengalaman. Argumen Robert Dahl (1915 -2014) tentang kekuasaan dengan menggambarkan bahwa "A memiliki kekuatan atas B sejauh ia bisa mendapatkan B untuk melakukan sesuatu yang tidak seharusnya dilakukan B," menuai banyak kritik..

Dahl menjelaskan bahwa ada 3 hal yang dibutuhkan untuk mengukuhkan relasi kekuasaan. (1). Ada waktu jeda, meski kecil atau pendek antara tindakan aktor untuk menunjukkan kekuasaannya dan tanggapan dari responden. Kekuasaan akan berjalan jika A mampu membuat a menanggapi serta menjalankan petunjuk A. (2). Dalam relasi kekuasaan tidak bisa ada jarak antara A dan a, jikapun ada jarak antara A dan a maka harus ada koneksi diantara keduanya. (3). A

${ }^{5}$ C Wright Mills, The Power Elite : New Edition (New York : Colombia University, 1956) hlm. 3-4

${ }^{6}$ Anthony Giddens, Politics, Sociology and Social Theory Encourages with Clasical an Contemporary Social Thought (California : Stanford University Press, 1995) hlm. 199) 
melibatkan usaha untuk dapat mempengaruhi a melakukan apa yang diperintahkan A. ${ }^{7}$

Kedua pemikiran Mills dan Dahl menyumbang konsep cara mengorganisasikan kekuasaan yang berangkat dari studi tentang perilaku negara dan sebuah kota dalam konteks masyarakat Amerika yang menghasilkan stuktur kekuasaan antara lain kekuasaan militer, kekuasaan elit ekonomi, kekuasaan civil society (NGO, Ormas dll) dan kekuasaan yang dimiliki oleh birokrasi pemerintahan. Dalam kajian keduanya melihat bahwa yang memiliki kekuasaan maka ia adalah yang kuat dan yang tidak memiliki kekuasaan adalah yang lemah. Pemilik keuasaan adalah pemenang yang akan membuat kebijakan-kebiakan yang harus dilakukan dan ditaati oleh yang lemah.

Steven Lukes (1941) mendeskripsikan teori "tiga wajah kekuasaan", yang disajikan dalam bukunya, Power: A Radical View. Teori ini memformulasikan kekuasaan dalam tiga cara: kekuasaan dalam pengambilan keputusan, kekuasaan dalam hal non-pengambilan keputusan, dan kekuasaan ideologis. Kekuasaan pengambilan keputusan adalah yang paling umum dari tiga dimensi yang lain. Analisis "wajah" ini berfokus pada preferensi kebijakan yang diterjemahkan melalui aksi politik. ${ }^{8}$ Kekuasaan non-pengambilan keputusan adalah keputusan yang menentukan agenda dalam perdebatan dan membuat masalah tertentu tidak dapat diterima untuk diskusikan di forum publik yang "sah". Menambahkan wajah ini memberi pandangan dua dimensi tentang kekuasaan yang memungkinkan untuk melakukan analisa masalah terkini dan potensial, memperluas fokus penelitian pada konflik yang dapat diamati dengan baik secara terang-terangan maupun tersembunyi. ${ }^{9}$ Kekuasaan ideologis memungkinkan seseorang untuk mempengaruhi keinginan dan pemikiran orang, bahkan membuat mereka menginginkan hal-hal yang bertentangan dengan kepentingan pribadi mereka sendiri (misalnya, menyebabkan perempuan mendukung masyarakat patriarkal). Lukes menawarkan dimensi ketiga ini sebagai "kritik menyeluruh" terhadap fokus perilaku dua dimensi pertama, ${ }^{10}$ melengkapi dan memperbaiki kekurangan pandangan sebelumnya, yang memungkinkan untuk melakukan analisa konflik laten dan yang dapat diamati. Lukes mengklaim bahwa kritik penuh atas

\footnotetext{
${ }^{7}$ Robert Dahl, Power, Department of Political Science (Yale University, 1957)

${ }^{8}$ Steven Lukes, Power : Radical View (New York: Palgrave Macmilan, 2005), hlm. 15

${ }^{9} \mathrm{Ibid}, \mathrm{hlm} .20$

${ }^{10} \mathrm{Ibid}, \mathrm{hlm} .24$
} 
kekuasaan harus mencakup kepentingan subjektif dan kepentingan "nyata" yang dimiliki oleh mereka yang tidak diikutsertakan dalam proses politik. ${ }^{11}$

Berlawanan dengan Mils dan Dahl salah satu pemikiran politik yang menarik diungkapkan oleh Foucault (1926 -1984). Memahami kekuasaan bagi Foucault bukan tentang siapa yang berkuasa dan dari mana kekuasaan itu hadir, namun kekuasan terkait dengan proses beroprasinya kekuasaan dan dengan cara apa kekuasaan tersebut dioperasikan. Pola-pola teori kekuasaan sebagaimana diungkap oleh Weber menurut Foucault tidak dapat menangkap kompleksitas relasi kakuasaan yang selalu berkembang dan bergerak dengan sangat dinamis. Konsep kekuasaan dalam masyarakat modern bukan sovereign power tetapi disiplinary power. Disiplinary power bukan konsep tentang kekuasaan yang dimiliki berdasarkan otoritas untuk mengontrol yang lain melainkan ia berfungsi dalam dan terhadap setiap relasi sosial, ekonomi, keluarga, dan seksualitas. Kekuasaan pada konteks ini bukan soal legalitas tindakan dan penghukuman dalam mengontrol yang lain, tetapi mengenai normalisasi kelakuan yang didisain dengan memanfaatkan kemampuan produktif dan reproduktif tubuh. Bentuk kekuasaan bukanlah dominasi antara yang lemah dan yang kuat atau yang powerfull dan powerless. Kekuasaab adalah bentuk kekuatan yang abstrak dimana kekuasaan tersebut beroprasi. ${ }^{12}$ Kekuasaan itu ada di mana-mana dan muncul dari berbagai kekuatan, terjadi secara mutlak dan tidak tergantung dari kesadaran manusia. Kekuasaan hanyalah sebuah strategi dan ia berlangsung di suatu tempat yang dimana terdapat sistem, aturan, susunan dna regulasi. Kekuasaan tidak datang dari luar melainkan kekuasaanlah yang menentukan susunan, aturan dan hubungan-hubungandari dalam yang memungkinkan semua hal bisa terjadi. ${ }^{13}$

Konsep yang melahirkan kekuasaan menurut Foucault adalah wacana atau discourse yang mempengaruhi institusi sosial dan praktik sosial. Kekuasaan tidak selalu dimaknai negatif, menekan dan menindas, namun kekuasaan bisa hadir dengan wajah positif dan produktif. Keberadaannya memang tidak disadari karena abstrak dan tidak disadari kehadirannya oleh individu sebagai sebuah penguasaan terhadap dirinya. Akan tetapi, kekuasaan dapat dilihat dari efek-efeknya. ${ }^{14}$

\footnotetext{
${ }^{11} \mathrm{Ibid}, \mathrm{hlm} .25$

${ }^{12}$ Michael Foucault, Seks dan Kekuasaan, Terj. S.H Rahayu (Jakarta : Gramedia Pustaka, 2000) hlm. 93-94

${ }^{13}$ Ibid, hlm. 144

${ }^{14}$ Michael Foucault, Power Knowledge : Selected Interviews and Others Writings 1972 - 1977 (New York : Pantheon Books, 1980), hlm. 118
} 
Foucault memang berbeda dalam memahami kekuasaan, pendapatnya berlawanan dengan term yang dikembangkan oleh kalangan weberian maupun marxian. Kekuasaan bukan merupakan fungsi dominasi dari suatu kelas yang didasarkan pada penguasaan atas ekonomi atau manipulasi ideologi (Marx), juga bukan dimiliki berkat suatu kharisma (Weber).

Secara implisit, Foucault sebenarnya ingin mengatakan bahwa rezim wacana itu merupakan bentuk dari kekuasaan. Wacana dapat berwujud sebagai praktikpraktik yang mengorganisasikan dan terorganisasikan, yang mengubah konstelasi sosial dan yang menghasilkan, dan wacana sebagai yang memiliki otonomi dan klaim atas kebenaran dan kontekstualisasi sebuah pengetahuan. Oleh karena itu, dalam pandangan Foucault yang terinspirasi oleh Nietzsche, tidak ada suatu kebenaran atau pengetahuan benar yang final dan bersifat universal. Kebenaran tidak lain merupakan kasus-kasus khusus mengenai kekeliruan yang pada suatu masa tertentu diakui otoritatif dan legitimate. Klaim kebenaran itu merupakan bentuk beroperasinya kekuasaan sebagai suatu wacana yang mempengaruhi institusi-institusi sosial dan praktik-praktik sosial. Masalah politik yang esensial bagi intelektual bukanlah untuk mengkritik isi ideologis yang seharusnya terkait dengan ilmu pengetahuan, atau untuk memastikan bahwa praktik ilmiahnya sendiri disertai ideologi yang benar. Tetapi justru untuk membentuk sebuah politik kebenaran yang baru. Memang temuan tersebut tidak mengubah kesadaran orang -atau apa yang ada di kepala mereka - tapi akan ada produksi rezim kebenaran kelembagaan politik, ekonomi, dan kelembagaan yang baru. ${ }^{15}$

Sebagai perbandingan pemikiran, pemikiran politik Islam yang lahir dari peradaban Timur Tengah juga menawarkan pemahaman tentang konsep kekuasaan. Satu pemikiran yang juga cukup menarik untuk diulas adalah tentang konsep power dalam kacamata sosiolog dan antropolog Muslim seperti Ibnu Khaldun ( 1332 - 1406) dan Al Mawardi. Konsep kekuasaan dalam Islam tentu akan sangat berbeda dengan konsep-konsep yang lahir di negara sekuler Eropa karena pengaruh kerangka berfikir yang berbeda pula. Pemikiran Islam yang banyak lahir dari belahan dunia timur dalam hal apapun bersifat teosentris, sedangkan pemikiran-pemikiran Eropa yang lahir dari belahan dunia Barat lebih bersifat antroposentris. Dalam konsep pemikiran Islam kekuasaan harus mengikutsetakan domain theologis yang didasarkan bukan hanya unsur imanen namun juga unsur transenden. Jika melihat konsep Faucault misal munculnya

${ }^{15}$ Ibid, hlm. 133 
konsep kekuasaan sangat erat kaintanya dengan rezim wacana. Klaim kebenaran ini merupakan bentuk beroprasinya kekuasaan sebagai wacana yang mempengaruhi bekerjanya isntitusi dan praktik sosial yang ada di masyarakat maka wacana kekuasaan sebahagai amanah Tuhan menjadi hal penting dalam konsep kekuasaan Ibnu Khaldun.

Kekuasaan secara prinsip menyangkut dua hal: 1) kekuasaan politik (alwilayah), 2) harta benda (al-amwal). Prinsip amanat dalam politik cukup jelas, bahwa makhluk adalah hamba-hamba Allah, dan para penguasa adalah wakil-wakil Allah untuk hamba-hambanya. Namun pada saat yang sama, penguasa juga merupakan wakil-wakil hamba atas diri mereka sendiri, seperti dua orang yang bermitra (al-syarikah) (Ibn Taimiyah, 1988: 19). Dengan kata lain, kekuasaan adalah titipan Allah dan rakyat kepada para pemimpin/penguasa untuk ditunaikan kepada yang berhak (Allah dan rakyat). Bila tidak, maka penguasa tersebut termasuk telah berkhianat kepada Allah, Rasul, dan rakyat. Ini tentu berbeda dengan pemahaman Al-Mawardi yang me-nganggap "amanat" lahir dari kontrak sosial antara rakyat sebagai trustor dan pemimpin sebagai trustee. ${ }^{16}$

Sedangkan dalam perspektif AL Mawardi pemegang kekuasaan di jabarkan ke dalam dua bentuk, pertama wazir tafwidh, yaitu wazir yang memiliki kekuasaan luas memutuskan berbagai kebijaksanaan kenegaraan. Ia juga merupakan koordinator kepala-kepala departeman. Wazir ini dapat dikatakan sebagai Perdana Menteri. Karena besarnya kekuasaan wazir tawfidh ini, maka orang yang menduduki jabatan ini merupakan orang-orang kepercayaan khalifah. Kedua, wazir tanfidz, yaitu waziryang hanya bertugas sebagai pelaksana kebijaksanaan yang digariskan oleh wazir tawfidh. Ia tidak berwenang menentukan kebijaksanaan sendiri. ${ }^{17}$

Kekuasaan dapat dimaknai sebagai bagian dari campur tangan manusia terhadap kekuasaan Tuhan yang terejawantah dalam penguasaan di dunia berupa kekuasaan politik dan ekonomi. Konsep kekuasaan sebagai titipan Allah menggambarkan bahwa ada batas yang harus di pegang oleh pemegang kekuasaan duniawi untuk bertindak sesuai dengan ketentuan dan aturan yang telah ditentukan dalam kitab suci. Di sini secara jelas menunjukkan bahwa Tuhan sebagai "kausa prima" atau pemilik kekuasaan tertinggi. Seorang penguasa juga

${ }^{16}$ Munawir Sjadzali, Islam dan Tata Negara: Ajaran, Sejarah dan Pemikiran (Jakarta: Universitas Indonesia Press, 1993) hlm. 85

${ }^{17}$ Ibid, hlm. 63 
harus menjalankan apa yang ada dalam konsensus yang telah disepakati baik di dunia maupun di akhirat. Konsep transenden dan imanen inilah yang menjadikan pemikiran Barat dan pemikiran Islam terkadang sulit dipertemukan dalam beberapa hal.

Kekuasaaan dalam terminologi yang dikembangkan oleh Ibnu Khaldun dan Al Mawardi adalah kekuasaan dari fungsi pengelolaan atau managerial yang jika terjadi pelanggaran terhadap ketentuan pengelolaan yang ada maka kekuasaan dapat dicabut oleh Kausa Prima meski bentuknya sangatlah abstrak. Kepercayaan terhadap term term theologis inilah yang akan menjadi dalih masyarakat melakukan kritik terhadap penguasa jika amanah yang diberikan tidak dijalankan sebagaimana mestinnya.

\section{Kekuasaan, Otoritas dan legitimasi}

Adalah Norman Uphoff yang mencoba mendeskripsikan dan mempertemukan berbagai pemikiran tentang kekuasaan, otoritas dan legitimasi. Dimulai dengan mempertanyakan term kekuasaan menurut weber dan mencoba membandingkannya dengan definisi serta penjabaran Talcot Parson, Uphoff mencoba melakukan kritik terhadap beberapa terminologi yang lahir dari pemikiran sebelumnya. Uphoff mengungkap bahwa pemikiran weber tentang kekuasaan sangat mendominasi pemikiran tentang kekuasaan dan otoritas serta legitimasi. Ia mencatat bahwa tidak ada definisi kekuasaan yang lebih sering dikutip daripada Weber dimana kekuasaann adalah kemungkinan satu hubungan sosial akan berada dalam posisi untuk melakukan kehendaknya sendiri sekalipun resistensi, terlepas dari dasar di mana probabilitas ini terletak.

Weber focus pada kemampuan untuk mencapai tujuan. Di inti dari konsep "kekuasaaan" apakah digunakan secara formal atau informal. Dua istilah dalam definisi ini, "probabilitas" dan "dasar", harus disorot karena sangat penting untuk membuat konsep tersebut kurang jelas. Istilah pertama tidak selalu tidak menunjukkan apa-apa hak pribadi. Berbagai penulis terkemuka menganggapnya sebagai kemajuan konseptual untuk menegaskan bahwa kekuasaan bukanlah sesuatu melainkan sebuah hubunganl.

Namun menurut Weber, sebuah pernyataan tentang kekuasaan hanyalah sebuah pernyataan tentang sebuah hubungan, yaitu, tentang probabilitas, bukan kepastian, seseorang akan bisa mencapai tujuannya. Weber tidak pernah 
mengatakan "kekuatan ada" atau Bahkan itu adalah sebuah hubungan. Dia mendefinisikannya hanya sebagai probabilitas. ${ }^{18}$ (Uphoff, 1989 : 299)

Otoritas adalah beberapa posisi atau peran khusus yang memungkinkan seseorang di dalamnya membuat perintah atas nama kelompok dan untuk mendukungnya penghargaan atau sanksi atas namanya. Perintah dibuat dan dipatuhi karena penghargaan atau sanksi yang dipekerjakan secara individu atau pribadi kapasitas, yang tidak memiliki klaim basis kelompok atau publik, tidak akan menjadi contoh otoritas tapi hubungan kepatuhan yang lebih umum paling baik dijelaskan dalam hal kekuasaan. (Uphoff, 1989 : 300)

Talcott Parsons menjelaskan bahwa kekuasaan memiliki keterkaitan dengan otoritas lebih jelas mengatakan bahwa kekuasaan adalah kemampuan untuk menjamin terlaksananya kewajiban-kewajiban yang mengikat, oleh kesatuankesatuan dalam suatu sistem organisasi kolektif. Kewajiban adalah sah jika menyangkut tujuan-tujuan kolektif. Jika ada perlawanan, maka pemaksaan melalui sanksi-sanksi negatif dianggap wajar, terlepas dari siapa yang melaksanakan pemaksaan itu. Dalam hal ini, Talcott melihat bahwa kekuasaan itu pendukung untuk mencapai tujuan bersama atau kolektif, sehingga untuk mencapai tujuan itu butuh suatu kekuasaan untuk mengatur hingga terlaksananya kewajiban-kewajiban yang mengikat, apabila ada yang tidak mengikuti ataupun melanggar akan mendapat sanksi. Dan dalam pelaksanaan sanksi tentunya ada pihak yang berwenang atau memiliki otoritas. ${ }^{19}$

Dalam terminologi politik Islam kekuasaan dan otoritas serta legitimasi dapat dijelaskan letika kita melihat terminologi Khilafah yang dijabarkan oleh Ibnu Khaldun maupun Al Mawardi. Khilafah menurut Ibn Khaldun adalah pemerintahan yang berlandaskan Agama yang memerintahkan rakyatnya sesuai dengan petunjuk Agama baik dalam hal keduniawian atau akhirat. Maka pemerintahan yang dilandaskan pada Agama disebut dengan Khilafah, Imamah atau Sulthananh. Sedang pemimpinnya disebut Khalifah, Imam atau Sulthan. Khilafah adalah pengganti Nabi Muhammad dengan tugas mempertahankan agama dan menjalankan kepemimpinan dunia. Lembaga imamah adalah wajib menurut hukum agama, yang dibuktikan dengan dibai'atnya Abu Bakar sebagai khalifah. Tetapi ada juga yang berpendapat, imamah wajib karena akal atau perlunya manusia terhadap organisasi sosial. Namun hukum wajibnya adalah

\footnotetext{
${ }^{18}$ Norman Uphoff, Distinguishing Power, hlm. 300

${ }^{19}$ Miriam Budiarjo, Dasar-dasar.
} 
fardhu kifayah (Muqaddimah: 191-193). Ibn Khaldun sendiri menetapkan 5 syarat bagi khalifah, Imam, ataupun Sulthan, yaitu: 1. Memiliki pengetahuan. 2. Memiliki sifat 'adil. 3. Mempunyai kemampuan. 4. Sehat Panca indra dan badannya. 5. Keturunan Quraisy. Pemikiran Ibn Khaldun dalam hal ini mirip dengan pemikiran Al-Mawardi ataupun Ghazali, bahwa khalifah haruslah dari golongan Quraisy. Tetapi Ibn Khaldun merealisasikannya dengan teori 'Ashabiyyah tersebut. Ibnu Qaldun mencoba mempertahankan status quo suku Quraisy.

Dalam berbagai penjabaran tentang kekuasaan legitimasi dan otoritas dalam dua berbagai perspektif di atas dapat kita lihat relasinya dengan menggunakan pandangan Walter Buckley yangmengungkap perbedaan antara kekuasaan dan wewenang, disensus dan konsensus, dan orientasi tujuan yang kompetitif atau kooperatif, yang sebenarnya saling terkait erat. Dari pandangan sistem modern, kesemua konsep tersebut terkait dalam proses sistemik yang kompleks, sehingga tidak satu pun dari mereka dapat dianggap sebagai determinan kausal, masingmasing muncul, dalam memiliki manifestasi sosial dan pribadi dan saling berpengaruh antara satu dan lainnya.

Gambar 6.3. Dari proses sistemik (Buckley,178)

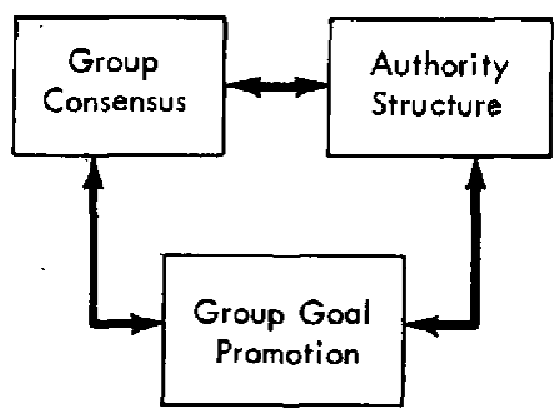

(A)

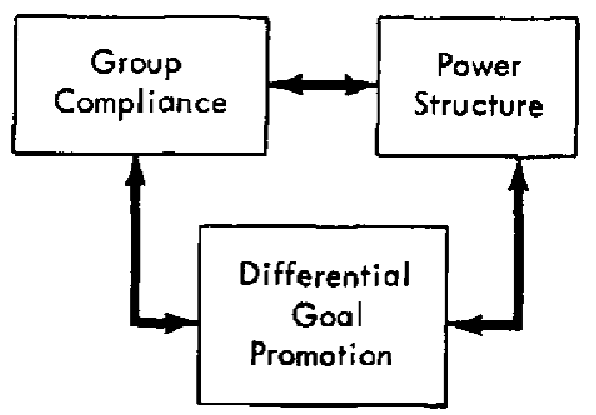

(B)

Diagram Buckley di atas munjukkan bahwa legitimasi yang digambarkan dalam diagram A bukan hanya sebuah fungsi struktur namun lebih dari itu ada konsensus yang dibentuk dari kepentingan serta tujuan individu dan kelompok. Sedangkan B adalah legitimasi yang dibentuk dari perbedaan tujuan antara 
individu, kelompok dan struktur yang ada dan tidak terjadi konsesnus bersama namun dissensus, namun model ini biasanya lebih berlangsung lama. ${ }^{20}$

Buckley menyebut bahwa ini bukan teori normatif yang menyatakan bagaimana pemerintah harus didirikan, namun teori sosiologis tentang stabilitas dan perubahan masyarakat: masyarakat yang berbasis pada kekuasaan tidak akan bertahan, atau akan beroperasi pada tingkat efisiensi yang rendah dan tingkat ketegangan, malintegrasi, dan atau konflik yang tinggi. Masyarakat berdasarkan legitimasi lebih cenderung bertahan, dan pada tingkat kepuasan pribadi, efektivitas kelompok, dan kerja sama yang lebih tinggi. Karena, Maclver berpendapat, kekuasaan tidak pernah memegang sebuah kelompok bersama; Dalam pemerintahan yang ada, otoritas semacam itu berbohong di belakang kekuasaan yang sia-sia. "Otoritas responsif terhadap struktur sosial yang mendasarinya," dan keuasaan yang dimiliki oleh pemerintah hanyalah instrumen otoritas yang bergantung pada daya tahannya "terutama pada mitos yang berlaku," ideologi, nilai, atau sistem pengetahuan, dari mereka yang menjadi sasarannya. "Mitos-mitos ini, yang timbul dari dan bermain di atas sifat sosial manusia, membawa kepada pemerintah sebuah ratifikasi yang tanpanya tidak ada pangeran atau parlemen, tidak ada tiran atau diktator, yang bisa memerintah rakyat." Maclver kemudian membahas "mitos otoritas" dan pelembagaannya di masyarakat yang semakin kompleks, konformasinya "oleh perangkat kelembagaan untuk meningkatkan formalitas." Perangkat yang membuat "pengudusan wewenang" ini mencakup perlengkapan kantor, penobatan dan lencana, upacara, gelar kehormatan, kekayaan, segregasi orang yang berwenang dari rekan-rekannya, dan sebagainya - aspek pelembagaan yang hampir seluruhnya terjadi. terbengkalai dalam sosiologi kontemporer seakan tidak lagi relevan di dunia modern. ${ }^{21}$

\section{Kekuasan dan Demokrasi}

Secara terminologis demokrasi dalam uraian Josefh A. Schmeter merupakan suatu perencanaan institusional untuk mencapai keputusan politik di mana indivudu-individu memperoleh kekuasaan untuk memutuskan dengan cara perjuangan kompetitif atas suatu rakyat. Sidney Hook menjabarkan demokrasi sebagai bentuk pemerintahan di mana keputusan pemerintah yang penting secara langsungmaupun tidak langsung didasarkan pada kesepakatan mayoritas yang

\footnotetext{
${ }^{20}$ Walter Buckley, Sociology and Modern System Theory, (New Jersey : Prentice Hall,
} INC. Englewood, 1987), hlm. 178

${ }^{21}$ Ibid, hlm. 180 
diberikan secara bebas dari rakyat dewasa. Sedangkan menurut Philippe $C$ Schmitter dan Terry Lynn Karl, demokrasi merupakan suatu sintem pemerintahan di mana pemerintah dimintai tanggung jawab atas tindakan-tindakan mereka di wilayah publik oleh warga negara, yang bertindak secara tidak langsung melalui kompetisidan kerjasama dari para wakil mereka yang terpilih. ${ }^{22}$

Dewasa ini terjadi kecenderungan global di mana demokrasi tidak sekedar menjadi wacana intelektual (intellectual discourse) melainkan juga "impian" (obsesi) politik berbagai negara, khususnya negara-negara berkembang. Berakhirnya perang dingin (Cold War) antara negara-negara adi daya (Amerika Serikat dan Uni Soviet) memiliki dampak positif bagi semaraknya gagasan dan proses demokratisasi di berbagai negara. Salah satu faktor penting yang menyebabkan demokrasi kini menjadi obsesi politik dunia adalah runtuhnya rezim-rezim komunis totaliter seperti Uni Soviet dan negara-negara Eropa Timur. Keruntuhan rezim-rezim tersebut menimbulkan kesan bahwa demokrasi merupakan senjata ampuh untuk melawan otoritarianisme dan totalitarianisme serta sitem anti demokrasi lainnya. Orang banyak berharap dari demokrasi. Dengan demokrasi diharapkan keputusan-keputusan yang menentukan kehidupan kolektif akan mendasarkan pada pertimbangan publik yang luas. Masyarakat demokrasi akan mengurangi ketidakadilan dan membuat pengorganisasian kehidupan kolektif mejadi lebih rasional. Selain itu demokrasi sering dianggap akan melindungi kebebasan warga serta mendorong pertumbuhan ekonomi. Demokrasi selalu diidentikkan dengan kebebasan, hormat terhadap martabat manusia, kesamaan, keadilan, keamanan dan pertumbuhan ekonomi. Demokrasi dipandang sebagai pengorganisasian masyarakat yang paling mencerminkan kehendak bersama karena tekanan partisipasi, representasi dan akuntabilitas. (Hariyatmoko, 2003) Demokrasi sebagai suatu konsep yang oleh Giovanni Satori dikatakan telah mendunia, seratus persen merupakan produk Barat. Karena itu nilai-nilai, pandangan dan cara hidup Barat tidak dapat dipisahkan dari konsep demokrasi, seperti individualisme, kapitalisme, liberalisme.

Wiliam Ebenstein mengemukakan beberapa kriteria dan dasar psikologis demokrasi. Pertama, empirisme rasional. Konsep ini merujuk pada keyakinan bahwa akal sehat, akal budi (reason) atau nalar manusia sangat penting dijadikan dasar demokrasi. Kedua, kepentingan individu sangat diutamakan, ini merupakan

${ }^{22}$ A. Ubaidillah, dkk (penyusun), Pendidikan Kewargaan Demokrasi, Ham dan Masyarakat Madani (Jakarta : IAIN Jakarta Press, 2000) 
kriteria terpenting. Kriteria inilah yang bisa dijadikan dasar untuk menentukan demokratis tidaknya suatu sistem pemerintahan. Ketiga, teori instrumental tentangnegara, menurut Ebenstein negara pada dasarnya bersifat instrumental. Negara seperti yang dirumuskan Plato dan Aristoteles hingga Marx, tidak lebih dari sekedar alat politik untuk mencapai tujuan bersama manusia. Keempat, prinsip voulentarisme (Voulentarism) atau prinsip kesukarelaan. Dalam sebuah negara demokratis, aksi-aksi atau kegiatan sosial politik haruslah didasarkan pada prinsipini. Pada dasranya negara demokrasi tidak mengenal mobilisasi paksaan. Kelima, konsep hukum dibalik hukum, hubungan antara negara dan masyarakat diatur olehhukum dan kedudukannya lebih tinggi dari hukum negara. Keenam, pementingan cara atau prosedur dalam kehidupan demokratis didasarkan pada kesadaran bahwatujuan tidak dapat dipisahkan dari cara atau alat yang digunakan. Ketujuh, musyawarah dan mufakat dan kedelapan adalah persamaan asasi manusia. $^{23}$

Larry Diamond menggambarkan lebih rinci kriteria demokrasi dalam system pemerintahan. Pertama, adanya kompetisi antar individu dan kelompok (terutama partai-partai politik) yang meluas dan bermakna serta tidak menggunakan daya paksa untuk merebutkan jabatan-jabatan pemerintahan regular. Kedua, adanya partisipasi politik yang tinggi dalam memilih pemimpin dan kebijakan-kebijakan minimal melalui pemilihan yang fair dan berkala serta tidak ada kelompok tertentu yang dikucilkan atau dikecualikan. Ketiga, adanya kebebasan sipil dan politik, antara lain kebebasan berpendapat, kebebasan pers, dan kebebasan berserikat yang cukup menjamin integrasi kompetisi dan partisipasi politik ${ }^{24}$ David Held memetakan perkembangan demokrasi cukup rigid dalam bukunya "Models of Democracy". Pertama, apa yang disebut dengan Clasical Democracy yang memiliki prinsip warga negara harus menikmati kesetaraan politik agar bebas memerintah dan diperintah secara bergantian. ${ }^{25}$ Kedua, Protective republicanism, yang memiliki prinsip partisipasi politik adalah hal penting dalam kebebasan individu, jika warga negara tidak menatur dirinya maka mereka akan didominasi oleh yang lain. ${ }^{26}$ Ketiga, Developmental republicanism, dimana warga negara harus

${ }^{23}$ Ahmad Suhelmi, Pemikiran Politik Barat : Kajian Sejarah Perkembangan Pemikiran Negara, Masyarakat dan Kekuasaan (Jakarta: PT Gramedia Pustaka Utama, 2001), hlm. 304308 1991)

${ }^{24}$ Mohtar Masoed, Negara Kapital dan Demokrasi (Yogyakarta : Pustaka Pelajar,

${ }^{25}$ David Held, Models of Democracy (USA : Polity Press, 2006), hlm. 27

${ }^{26}$ Ibid, hlm. 28 
menikmati kesetaraan politik dan ekonomi agar tidak ada yang menguasai orang lain dan semua dapat menikmati kebebasan dan pembangunan yang sama dalam proses penentuan masib sendiri untuk kebaikan bersama. ${ }^{27}$ Keempat adalah Liberal Democracy, Warga negara memerlukan perlindungan dari negara, dan juga satu sama lain untuk memastikan bahwa mereka yang mengatur kebijakan yang sepadan dengan kepentingan warga negara secara keseluruhan.

Gambaran bentuk kekuasaan dan demokrasi dalam Islam juga dapat kita lihat dari penjabaran dan penjelasam Al Mawardi. Imam (yang dalam pemikiran al mawardi adalah seorang raja, presiden, sultan) merupakan sesuatu yang niscaya.Artinya, keberadaannya sangat penting dalam suatu masyarakat atau negara. Karena itu, jelasnya, tanpa imam akan timbul suasana chaos. Jabatan imamah (kepemimpinan) dinilai sah apabila memenuhi dua metodologi, yaitu: Pertama, dia dipilih oleh parlemen (ahlul halli wal aqdi) Mereka inilah yang memiliki wewenang untuk mengikat dan mengurai, atau juga disebut model Al Ikhtiar. Kedua, ditunjuk oleh imam sebelumnya. Model pertama selaras dengan demokrasi dalam konteks modern.

Al-Mawardi menunjukkan betapa aturan agama dan teori kekhalifahan Sunni yang telah diterima dapat ditafsir ulang dan dikembangkan sedemikian rupa, sehingga mengabaikan hubungan kekuasaan yang ad. Teorinya membuat para penguasa (lokal) secara tekhnis bergantung kepada persetujuan Khalifah demi legitimasi mereka. Ia meletakkan dasar-dasar intelektual bagi kebangkitan kembali Kekhalifahan Abbasiyah, yang sangat mungkin menjadi lebih luas lagi, kecuali bagi orang Mongol. Namun pada kenyataannya, sebagian besar teori ini bertahan sebagai wacana teoritis, teori ini tidak pernah diuji dalam kenyataannya.

Dalam banyak hal, khususnya dalam konteks demokrasi dan politik modern, sulit rasanya menerapkan konsep dan pemikiran Al Mawardi secara penuh. Barangkali, hanya beberapa bagian, semisal dalam masalah kualifikasi dan pengangkatan seorang imam, juga masalah pembagian kekuasaan di bawahnya. Namun demikian, wacana Al Mawardi ini sangat berbobot ketika diletakkan

\section{${ }^{27}$ Ibid, hlm. 52}


sebagai antitesis dari kegagalan teori demokrasi, dan sumbangan khazanah berharga bagi perkembangan politik Islam modern.

\section{E. Kesimpulan}

Dalam kajian teori politik konsepsi power, demokrasi dan legitimasi terus berkembang sesuai dengan perkembangan kondisi sosial dan politik setra ekonomi yang bergerak dengan sangat dinamis di berbagai ruang. Oleh karena itu studi tentang power dan demokrasi serta legitimasi harus memperhatikan aspek konteks dengan melihat latar belakang sosial dan politik di setiap perkembangan masing-masing teori. Bagaimana power atau kekuasaan beroperasi dan bagaimana discourse tentang kekuasaan tersebut berkembang menjadi penting diperhatikan.

Dengan melihat berbagai perkembangan konsep power dan demokrasi maka rumusan tentang kekuasaan dalam konteks masyarakat modern juga dapat menghasilkan rumusan baru yang berangkat dari kasus yang sangat lokal namun bisa menjadi representasi internasional karena mewakili sebagai konsep yang membantah atau mendukung bahkan menambahi konsep-konsep yang telah dikembangkan sebelumnya. 


\section{DAFTAR PUSTAKA}

Abdillah, Masykuri, 1999, Demokrasi Di Persimpangan Makna, Yogyakarta: Tiara Wacana.

Bierstadt, Robert, 1950, “An Analysis of Social Power,” American Sociological Review, volume 15

Buckley, Walter, tt, Sociology and Modern System Theory, Prentice Hall, INC. Englewood, New Jersey.

Budiarjo, Miriam, 1996, Demokrasi di Indonesia; Demokrasi Parlementer danDemokrasi Pancasila, Jakarta: Gramedia.

Dahl, Robert A, 1957, Power, Department oj Political Science, Yale University

Foucault, Michel, 1980, Power Knowledge Selected Interviews and Others Writings 1972 - 1977, New York : Pantheon Books.

Foucault, Michel, 2000, Seks dan Kekuasaan, trj. S.H Rahayu, Jakarta, Gramedia.

Giddens, Anthony, 1995, Politics, Sociology and Social Theory Encourages with Clasical an Contemporary Social Thought, California ; Stanford University Press.

Hariyatmoko, 2003, Etika politik dan Kekuasaan, Jakarta : Kompas.

Held, David, 2006, Models of Democracy, USA : Polity Press.

Heywood, Andrew 2004, Political Theory an Introduction, New York: Palgrave Macmilan.

Lukes, Steven, 2005, Power : Radical View, New York: Palgrave Macmilan.

Masoed, Mohtar, 1991, Negara Kapital dan Demokrasi, Yogyakarta : Pustaka Pelajar,.

Mills, C Wright, 1956, The Power Elite New Edition, Colombia University.

Miriam, Budiarjo, 2008. Dasar-dasar Ilmu Politik.

Sjadzali, H. Munawir M.A., 1993, Islam dan Tata Negara: Ajaran, Sejarah dan Pemikiran, Jakarta: Universitas Indonesia Press. 
Suhelmi, Ahmad 2001, Pemikiran Politik Barat Kajian Sejarah Perkembangan Pemikiran Negara, Masyarakat dan Kekuasaan Jakarta: PT Gramedia Pustaka Utama.

Ubaidillah, A. dkk (penysn), 2000, Pendidikan Kewargaan Demokrasi, Ham dan Masyarakat Madani, Jakarta : IAIN Jakarta Press.

Uphoff, Norman, 1989, Distinguishing Power, Authority \& Legitimacy: Taking Max Weber at his Word by Using Resources-ExchangeA nalysis, Journal Polity, Vol. 22, No. 2. 
